\title{
Commentarie on the letter to the editor
}

\section{Familicide attempt: case report of a forensic psychiatric evaluation}

Commentarie on the letter to the editor/ Rev Psiq Clin. 2013;40(3):128

\section{DANIEL MarTins De BarRos}

Psychiatrist at the Forensic Psychiatry and Psychology Unit, Department and Institute of Psychiatry, University of São Paulo Medical School (FMUSP), São Paulo, SP, Brazil.

The letter to the editor "Attempted familicídio: case report of forensic psychiatric"1 exam brings up a subject that, although low in incidence, features a high-impact, not only by mobilizing public opinion $^{2}$, but also for its high degree of unpredictability ${ }^{3}$.

There are few studies on the subject, most trying to find theoretical explanations for the crime, with no consensus in the literature ${ }^{3}$, or to set up an epidemiological profile of the perpetrator ${ }^{3}$, where a pattern can be extracted, possibly allowing the development of strategies to prevent future crimes.

Familicide can be considered a subcategory of mass murder, defined as the killing of four or more people in a single incident committed by an individual ${ }^{4}$. The main differences are that in the latter the victims are usually not all of the family of the perpetrator, while in the first number of deaths tends to be lower ${ }^{3}$.

For the mental health professional is crucial to know the main risk factors for this crime, since most of those involved in familicide has had some mental disorder in the past ${ }^{1,3}$. They are usually married men with a history of depression and in possession of a gun ${ }^{3}$, although in the present report the attempted of murder has been made with another instrument. It is worth noting that the event triggering the crime is usually some sort of break, be it loss of employment, threat or consummation of marital separation, leading to a catathymic state in which the intensity of emotions can distort the critical judgment and culminate in crimes.

Thus, the same way that good clinical practice demands that we investigate suicidal thoughts in depressed patients, this report reveals that it may be important to check if patients with this profile present, combined with its clinical symptoms, an absence of alternative ideas and thoughts elimination of himself and his family.

\section{References}

1. Telles LEB, Correa IHC, Blank P. Tentativa de familicídio: relato de caso de perícia psiquiátrica forense. Rev Psiq Clín. 2013;40(3):127.

2. Sisask M, Mark L, Värnik A. Internet comments elicited by media portrayal of a familicide-suicide case. Crisis. 2012;33(4):222-9.

3. Malmquist CP. Psychiatric aspects of familicide. Bull Am Acad Psychiatry Law. 1980;8(3):298-304.

4. Morton RJ (Editor). Serial Murder: Multi-Disciplinary Perspectives for Investigators. US Department of Justice. 2005. p. 8.

5. Schlesinger LB. Familicide, depression and catathymic process. J Forensic Sci. 2000;45(1):200-3. 